International Journal of Instruction e-ISSN: 1308-1470 • www.e-iji.net
October $2017 \bullet$ Vol.10, No.4

p-ISSN: 1694-609X

pp. $39-50$

Received: 04/04/2017

Revision: 09/06/2017

Accepted: 14/06/2017

\title{
The Influence of Income, Experience, and Academic Qualification on the Early Childhood Education Teachers' Creativity in Semarang, Indonesia
}

\author{
Risky Setiawan \\ Dr., Early Childhood Department, Institute of Education Veteran Semarang, Indonesia, \\ setiawan.risky@gmail.com
}

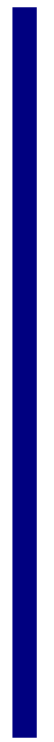

This study aims to determine: (1) the intercorrelation between income, experience, and academic qualification with the early childhood education teachers' teaching creativity; (2) to find out the dominant factors that affect the ability of teachers' Creativity in Semarang. This research uses an experimental design with four variables, including teachers' income (X1), experience (X2), academic qualification $(\mathrm{X} 3)$, and teaching creativity $(\mathrm{Y})$. The research objects are the randomly selected 56 early childhood education teachers in Semarang. The questionnaire instrument is validated with a construct validity test while the quantitative analysis is conducted through both intercorrelation and multiple regression analysis. The results show that: (1) the descriptive analytical results show that the average education level range is 1.4 or Senior High School (SMA) and 2 years diploma (D2). Meanwhile, the early childhood teachers' income is at the average of 191, 991 IDR or is still categorized into very low. In addition, the early childhood teachers' teaching experience is at the average of 8.7 years or is categorized as high. Furthermore, the dependent variable (creativity) of the early childhood teachers is categorized into high; (2) teaching experience (0.549) and education level (0.617) significantly influence the early childhood teachers' creativity, while income $(-0.107)$ does not significantly influence the early childhood teachers' teaching creativity.

Keywords: influence, income, experience, education, early childhood education teachers

\section{INTRODUCTION}

Early childhood potential intelligences which consist of: (1) creativity and emotional (2) physiological, and (3) mathematic and linguistic intelligences (Directorate General of Early Childhood Education, 2012) may be optimized with fun and effective teachinglearning stimulations. Gardner (2006) mentions that seven children's intelligences (multiple intelligences) may be optimized are on: (1) Mathematics, (2) sciences, (3) music, (4) languages, (5) visual arts, (6) kinesthetic creativities, and (7) social. Thus, several effective efforts should be made to optimize those all early childhood

Citation: Setiawan, R. (2017). The Influence of Income, Experience, and Academic Qualification on the Early Chilhood Education Teachers' Creativity in Semarang, Indonesia. International Journal of Instruction, 10(4), 39-50. https://doi.org/10.12973/iji.2017.1043a 
intelligences. Stimulation application of early childhood intelligence may not be separated from the educators' roles, especially teachers'. Kindergarten/early childhood education teachers have very important roles in developing the early childhood education students' potentials. The teachers' roles as the closest people to children at schools should create fun atmospheres and be the loved ones. Those may result in children easiness to gain stimulus from activities conducted by educators both as tutors and playmates. The educators' roles as friends, models, motivators and facilitators can make children enjoy coming to school and result in meaningful learning processes. Thus, maturity on willingness and ability is highly required both physically (excellent condition) and intellectually. This professionalism should be viewed as sustainable processes.

Kindergarten/early childhood education teachers are spread throughout the country, starting from big cities to the most remote areas, with various backgrounds either education or social and culture. Kindergarten/early childhood education teachers are considered as the major factors due to the education quality of the nation since kindergarten/early childhood education teachers are those who programmatically interact with learners during the learning processes. Kindergarten and early childhood learning quality is a factor which has become the major issue due to the kindergarten/early childhood teachers' low education qualification. The success of early childhood programs is highly determined by the availability of educators with qualified education who are mostly not the civil servants yet. In facts, they are just common people with various education backgrounds with different competencies and qualifications. The provision and development of educators', education staffs', and the early childhood education programs' quality is the key to success (Ministry of Education and Culture, Director General of Early Childhood, non-formal and informal education, 2012).

Education level and creativity have a very closely relationship. The Torrence theory states that one indicator influencing the creative thinking expression or development is due to someone's education level (Bloomberg, 1973: 141). In addition to education level, income also determines the early childhood education teachers' performance. The Chairman of Commission IV of the Regional Representative House of Purbalingga assesses that the welfare honorarium given to kindergarten/early childhood education teachers' of Madrasah Diniyah (Madin) in Purbalingga is very low (inappropriate). Kindergarten/early childhood education teachers only receive 75,000 IDR/month while Madrasah Diniyah teachers get 70,000 IDR/month (Suara Merdeka, Nop 2014). Due to the facts and the obtained data, the assumption on relationship between income, teaching experience, as well as academic qualification and the kindergarten/early childhood education teachers' teaching creativity in Semarang is necessary to conduct.

\section{CONTEXT AND REVIEW OF LITERATURE}

\section{Teaching Creativity}

Bloomberg (1973) says most of the more obvious contributors to creative thinking are abilities in the divergent-production category. The factors of fluency, flexibility, 
originality, and elaboration are in that category. Charter (2009) states the term creativity refers to mental processes that lead to solutions, ideas, concepts, artistic expression, theories or products that are unique and novel. That's why teaching creativity is very important as a part in educational program and learning objects.

Teacher assessment creativity process is developed by Risky (2016). That product can measure the creativity process on convergent and divergent thinking.

\section{Creativity Test of Teaching}

Creativity test is the development of three elements in construct theory; person factors, convergent thinking factor, and divergent thinking factor. Some kind of test of creativity developed by researcher example; picture completion Test (Frank Barron's), creativity test for children (Guildford), ask and guess test (Torrance), and remote associates test (Sarnoff Megnick). Akbari (2012) says the solution to a coherent triad, therefore, gets activation from each stimulus word adds incrementally to activation of the solution, even if that level of activation does not exceed a threshold for conscious awareness. Base on the research Mednick (1962) it should be clear that an individual without the requisite elements in his response repertoire will not be able to combine them so as to arrive at a creative solution. An architect who does not know of the existence of a new material can hardly be expected to use it creatively.

Torrance (1976) in creativity measurement has five elements: (1) fluency is the number of relevant ideas; shows an ability to produce a number of figural images; (2) originality means the number of statistically infrequent ideas; shows an ability to produce uncommon or unique responses. The scoring procedure counts the most common responses as 0 and all other legitimate responses as 1 . The originality lists have been prepared for each item on the basis of normative data, which are readily memorized by scorers; (3) elaboration that's the number of added ideas; demonstrates the subject's ability to develop and elaborate on ideas; (4) abstractness of titles is the degree beyond labeling; based on the idea that creativity requires an abstraction of thought; and the last (5) resistance to premature closure means the degree of psychological openness; based on the belief that creative behavior requires a person to consider a variety of information when processing information and to keep an "open mind".

\section{METHOD}

This research use a quantitative approach with an influence testing technique also called a multiple regression test aiming to provide explanations on relationship between research variables and to analyze each factor's influence, covering income, teaching experience, and academic qualification based on the proposed hypotheses. The research variables consist of independent variables consisting of income (X1), teaching experience (X2), educational level (X3) to have an affect on dependent variable is creativity teacher $(\mathrm{Y})$.

The research subjects are the early childhood education teachers in Semarang, Indonesia with a total sample of 56 early childhood teachers collected using a proportional random sampling technique of the total population 75 honorary early childhood teachers. 


\section{Data Gathering Instruments.}

The research data collection techniques use questionnaire and test instruments with Likert scale and are then analyzed with EFA (Exploratory Factor Analysis) using modern item response theory method.

The research instrument based on objective assessment of Developing Creative Thinking Kindergarten Teacher as follows. Instruments developed and adopted from instruments of the Torrance Test of Creative Thingking, Glaveanu, Vlad Petre (2014), Joe Y.F. (2011) and Remote Associates Test by Akbari (2012), Mednick S.A (1962).

Table 1

Research Instruments

\begin{tabular}{|c|c|c|c|c|}
\hline No & Element & Category & Indicator & Instrument Shape \\
\hline \multirow[t]{4}{*}{1} & $\begin{array}{l}\text { Test takers' } \\
\text { condition } \\
\text { (Personal Test) }\end{array}$ & Pedagogy & $\begin{array}{l}\text { Childhood learning in } \\
\text { various activities }\end{array}$ & $\begin{array}{l}\text { Respondents' } \mathrm{VC} \text { and } \\
\text { their teaching } \\
\text { experiences }\end{array}$ \\
\hline & Instrumen I & Professional & $\begin{array}{l}\text { Teaching materials and } \\
\text { teachers' experience }\end{array}$ & Ordinal Questionnaire \\
\hline & $\begin{array}{l}\text { (measuring } \\
\text { Resistance to } \\
\text { Premature Closure) }\end{array}$ & Social & $\begin{array}{l}\text { Communication within } \\
\text { learning atmosphere }\end{array}$ & $\begin{array}{l}\text { Data } \\
\text { (Graded data's) }\end{array}$ \\
\hline & $\begin{array}{l}\text { (Remote Associates } \\
\text { Test) }\end{array}$ & Personality & $\begin{array}{l}\text { Kindergarten/early } \\
\text { childhood Education } \\
\text { teachers' personality }\end{array}$ & Personal Testing \\
\hline \multirow[t]{4}{*}{2} & $\begin{array}{l}\text { Teachers' creativity } \\
\text { (Torrence Test of } \\
\text { Creativity } \\
\text { Thingking) }\end{array}$ & $\begin{array}{l}\text { Use and } \\
\text { Different }\end{array}$ & $\begin{array}{l}\text { Noticing things } \\
\text { differently and using the } \\
\text { provided object shapes }\end{array}$ & $\begin{array}{l}\text { Figural Testing } \\
\text { (Figure) } \\
\text { With based times }\end{array}$ \\
\hline & Instrumen II & $\begin{array}{l}\text { Founded } \\
\text { and }\end{array}$ & $\begin{array}{l}\text { discovering and } \\
\text { combining various and }\end{array}$ & $\begin{array}{l}\text { Figural Testing } \\
\text { (Figure) }\end{array}$ \\
\hline & $\begin{array}{l}\text { (Measuring } \\
\text { Originality, }\end{array}$ & Combine & different object shapes & With based times \\
\hline & $\begin{array}{l}\text { Elaboration and } \\
\text { Abstractness) }\end{array}$ & $\begin{array}{l}\text { Complete } \\
\text { and } \\
\text { Conclude }\end{array}$ & $\begin{array}{l}\text { completing and } \\
\text { concluding the provided } \\
\text { basic shapes with object / } \\
\text { shape options }\end{array}$ & $\begin{array}{l}\text { Theme- Based Figural } \\
\text { Selection and } \\
\text { Conclusion Testing } \\
\text { (essay) }\end{array}$ \\
\hline
\end{tabular}

Content Validity is used to validate the research instruments. Allen (1979: 96) states that as content validity is derived from subjective considerations, the validity is proven with the subject errors. To guarantee the content validity, then the whole questions are made based on theories and documents related to the implementation of Education, Training, and Supervision of the chief organizer of the programs. The instruments of this study are logically and empirically validated by expert judgment. Logical validity consists of content, construction, and language. Instrument testing is conducted with the unused validity in which instruments are directly used to respondents and then analyzed by removing those invalid and unreliable items. 
According to Djemari (2008), the accepted items should have differential power index of $>0.3$, those with differential power index of between $0.1-0.3$ should be revised, while others with the differential power index of $<0.1$ are not accepted. Ebel and Frisbie also mention the standards of differential power index as follows: $>0.4$ (excellent items), 0.3-0.39 (slight revisions are required), 0.2 - 0:29 (revisions are required), <0:19 (items should be eliminated). Data are then analyzed using a regression analysis with the equation of $\mathrm{Y}=\mathrm{a}+\mathrm{bX}$ (Ebel, 1986) by describing the influence of each factor (unstandardized coefficient).

\section{FINDINGS}

\section{Each Variable Data Description}

The collected data are then analyzed with a descriptive statistics using SPSS 23 for Windows by including some criteria on data homogeneity and linearity. The descriptive statistic results of each variable are presented as follows.

Table 2

Descriptive Statistics

\begin{tabular}{llll}
\hline & Mean & Std. Deviation & $\mathrm{N}$ \\
\hline Creativity & 3.0482 & .30030 & 56 \\
\hline Income & 191991.0714 & 277110.91463 & 56 \\
\hline Experience & 8.7143 & 7.50930 & 56 \\
\hline Education & 1.4821 & .73833 & 56 \\
\hline
\end{tabular}

Based on the data presented on table, it shows that that the average education level is 1.4 or at Senior High School (SMA) and 2 Years Diploma (D2) level. Meanwhile, the early childhood education teachers' income is at the average of 191991 IDR or is still categorized as very low. The early childhood education teachers' teaching experience factor is at the average of 8.7 years or categorized as high. In addition, the early childhood education teachers' dependent variable (creativity) is in high category.

\section{Hypothesis Testing}

A hypothesis is an assumption about a population parameter. Hypothesis testing aims to make a statistical conclution about accepting or not accepting the hypothesis. The best way to determine of a hypothesis was true would be to examine the entire population. Null Hypothesis $(\mathrm{Hō})$ in research there is not a relationship between dependent variable and independent variables. While the Alternate Hypothesis ( $\mathrm{Ha})$ is a relationship between dependent variable and independent variables.

Based on the obtained data, the coeficient correlations results are as follows: 
Table 3

Coeficient Correlations Results

\begin{tabular}{llcccc}
\hline & & Creativity & Income & Experience & Education \\
\hline Pearson & Creativity & 1.000 & -.107 & $.549^{* *}$ & $.617^{* *}$ \\
\cline { 2 - 6 } Correlation & Income & -.107 & 1.000 & .609 & -.050 \\
\cline { 2 - 6 } & Experience & $.549^{* *}$ & .609 & 1.000 & .097 \\
\cline { 2 - 6 } & Education & $.617^{* *}$ & -.050 & .097 & 1.000 \\
\hline \multirow{3}{*}{ Sig. (1-tailed) } & Creativity &. & .003 & .000 & .000 \\
\cline { 2 - 6 } & Income & .003 &. & .000 & .000 \\
\cline { 2 - 6 } & Experience & .000 & .000 &. & .000 \\
\cline { 2 - 6 } & Education & .000 & .000 & .000 &. \\
\hline $\mathrm{N}$ & Creativity & 56 & 56 & 56 & 56 \\
\cline { 2 - 6 } & Income & 56 & 56 & 56 & 56 \\
\cline { 2 - 6 } & Experience & 56 & 56 & 56 & 56 \\
\cline { 2 - 6 } & Education & 56 & 56 & 56 & \\
\hline
\end{tabular}

The coefficient correlations results show that the correlation between income and creativity is -0.107 or $\mathrm{H} 0$ is accepted (sig. $=0.03<0.05$ ), meaning that the increasing income does not influence the early childhood education teachers' creativity. Meanwhile, the correlation between teaching experience and creativity is 0.549 or $\mathrm{H} 0$ is refused (sig. $=0.00<0.05$ ), meaning that increasing income is correlated with the early childhood education teachers' creativity. In addition, education level has a correlation with the early childhood teachers' creativity with a value of 0.617 or $\mathrm{H} 0$ is rejected, meaning that there is a significant correlation between education level and the early childhood education teachers' learning creativity. Negative values show the opposite direction relationship. However, as the value is still below $r$ table, the correlation between income and creativity is not significant.

\section{DISCUSSION}

The Influence of Income, experience and education level on the early childhood education Teachers' Creativity

$R$ value calculation or the influence of those four variables and $R^{2}$ or the terminated coefficient value may result in information level explained by variable Y. Meanwhile, the obtained information will be described by SPSS output in the following summary model.

Table 4

Summary Model

\begin{tabular}{cccccc}
\hline Model & $\mathrm{R}$ & $\begin{array}{c}\mathrm{R} \\
\text { Square }\end{array}$ & $\begin{array}{c}\text { Adjusted } \\
\text { R Square }\end{array}$ & $\begin{array}{c}\text { Std. Error of } \\
\text { the Estimate }\end{array}$ & Durbin-Watson \\
\hline 1 &, $624^{\mathrm{a}}$ &, 389 &, 369 & 7,93843 & 1,463 \\
\hline a. Predictors: (Constant), Education, Income, Experience & & \\
\hline \multicolumn{2}{l}{ b. Dependent Variable: Creativity } \\
\hline
\end{tabular}


SPSS calculation results show that $R=0624$, with $R^{2}=0389$. $R$ value is the relationship between income, experience, as well as education and the early childhood education teachers' teaching creativity. Meanwhile, to know the created quality of multiple linear regression model, notify the determination coefficient value $(\mathrm{R}$ square $)=0369$. It shows the information that $37 \%$ of the early childhood education teachers' creativity value may be explained by the data of income, experience and education. While the remaining information of $63 \%$ the early childhood education teachers' creativity value may not be explained by those independent variables.

\section{Autocorrelation}

From summary table, it shows that the value of Durbin-Watson $=1.463$. The use of this value aims to examine whether there is autocorrelation or not. The decision is made based on: If the Durbin-Watson value is in the range of $-2 \leq$ Durbin-Watson $\leq 2$, then there is no autocorrelation; if not in the range, there is an autocorrelation. In this case, the resulted value is 1.463 which is in the range $-2 \leq n \leq 2$, then between income, experience, and education variable, there is no autocorrelation.

Table 5

Analysis of Varians (ANOVA)

\begin{tabular}{llccccc}
\hline Model & & Sum of Squares & df & Mean Square & F & Sig. \\
\hline \multirow{2}{*}{1} & Regression & 2445.846 & 3 & 1222.133 & 1.511 & $.000^{\mathrm{b}}$ \\
\cline { 2 - 7 } & Residual & 3844.139 & 52 & 63.088 & & \\
\cline { 2 - 7 } & Total & 6289.984 & 55 & & & \\
\hline
\end{tabular}

\section{The Resulted Regression Model Coefficients}

The influence value or amount of regression coefficients may be seen by combining the regression equation of $\mathrm{Y}=\mathrm{a}+\mathrm{bx}$ by noticing both coefficient $\mathrm{a}$ and $\mathrm{b}$ as well as the resulted constants. By combining the coefficient values into the regression equation, the predicted amount may be resulted by each factor or variable. The coefficient explanation may be seen in Table 6.

Table 6

Coefficients Regression

\begin{tabular}{|c|c|c|c|c|c|c|}
\hline & \multirow[t]{2}{*}{ Model } & \multicolumn{2}{|c|}{$\begin{array}{l}\text { Unstandardized } \\
\text { Coefficients }\end{array}$} & \multirow{2}{*}{$\begin{array}{c}\begin{array}{c}\text { Standardized } \\
\text { Coefficients }\end{array} \\
\text { Beta } \\
\end{array}$} & \multirow[t]{2}{*}{$\mathrm{t}$} & \multirow[t]{2}{*}{ Sig. } \\
\hline & & B & Std. Error & & & \\
\hline \multirow[t]{4}{*}{1} & (Constant) & 26.802 & 5.499 & & 31.114 & .000 \\
\hline & Income & -.058 & .007 & -.113 & -.667 & .508 \\
\hline & Experience & .297 & .119 & .318 & 2.053 & .015 \\
\hline & Education & .225 & .076 & -.143 & 2.945 & .005 \\
\hline
\end{tabular}

$\mathrm{T}$ test in multiple linear regression is intended to test whether the predicted parameters (regression coefficients and constants) to estimate the equation/multiple linear regression has already been appropriate or not. Here, appropriate means that it may explain the independent variable's behaviors to influence the dependent ones. The 
estimated parameters in linear regression consist of intercept (constant) and slope (coefficient in linear equation). In this section, $\mathrm{t}$ test focuses on slope parameter (regression coefficient) only. Thus, the intended $t$ test is the regression coefficient test. The testing results may be seen in the coefficient table. The interpretations following means: (1) T test result on income variable is $0.508>0.05$. It means that income variable does not significantly influence the early childhood education teachers' creativity; (2) T test result on income variable is $0.015<0.05$. It means that the teaching experience variable significantly influences the early childhood education teachers' creativity; (3) $\mathrm{T}$ test result on education level is $0.005<0.05$. It means that education level variable significantly influences the early childhood education teachers' creativity.

After multivariate analysis is conducted, an equation is resulted and shown in table 5 by noticing the values presented in column B. Thus, off all the obtained data, the regression equation resulted from the influence value testing on income, experience and education to the creativity level of the early childhood education teachers in Semarang is $\mathrm{Y}=$ 26.802-0.058X1 + 0.297X2 + 0.225X3.

\section{CONCLUSION}

From the research results, it can be concluded that:

The descriptive analytical results show that the average education level is 1.4 or Senior High School (SMA) and 2 years Diploma (D2). The average income of the early childhood education teachers is 191,991 IDR or is still categorized as very low. The teaching experience factor of the early childhood education teachers is at the average of 8.7 years or is categorized as high. The dependent variable (creativity) of teachers is categorized as high.

Teaching experience and education level variable significantly influence the early childhood education teachers' creativity. While income variable income does not significantly influence the early childhood education teachers' creativity. This is similar to the results of the research Kyung Hee Kim (2006), that distributed creativity thingking with measure of the creative individual by test and the result of the research show as following teachers can develop teaching creativity easily using their experience and professionalism.

Suggestions and recommendations generated from the research results are as follows: The Government should pay more attention to improve the early childhood education teachers' creativity through education and training to develop their teaching experience; Regulations on teaching certificate based on the minimum qualification of strata 1 for the early childhood education teachers in the field of Early Childhood Education should be applied to improve the creativity and effectiveness of children's learning activities in the classroom. 


\section{REFERENCES}

Chermahini, S. A., Hickendorff, M., \& Hommel, B. (2012). Development and validity of a Dutch version of the Remote Associates Task: An item-response theory approach. Thinking Skills and Creativity, 7(3), 177-186.

Allen, M. J., \& Yen, W. M. (1979). Introduction to measurement theory. Belmont CA: Wadsworth.

Bloomberg, M. (1973). Creativity, theory and research. United States of America: United Printing Service.

Carter, P. (2009). Test and assess your brain quotient. Philadelpia, USA: Kogan Page.

Directorate General of Early Childhood Education (2012). Program implementation guidelines early childhood education, Jakarta.

Djemari, M. (2008). Teknik penyusunan instrumen tes dan nontes. Yogyakarta: Mitra Cendikia Jogjakarta.

Ebel, R. L. (1986). Essential of educational measurement, third edition. New Jersey: Prentice Hall.

Gardner, H. (2006). Multiple intellegences. New York USA: Basic Book.

Glaveanu, V. P. (2014). Distributed creativity thingking outside the box of the creative individual. Aalborg University New York: Spiger.

Joe, Y. F. (2011). An Introduction to critical thinking and creativity: Think more, think better. New Jersey: Wiley Publication.

Kyung, H. K. (2006). Can we trust creativity test: a review of the torrance test of creative thingking (TTCT). Creativity Research Journal, 18 (1), 3-14.

Mednick, S. A. (1962). The associative basis of the creative process. Psychological review, 69(3), 220-232.

Ministry of Education and Culture. Director General of Early Childhood (2012).

Program implementation guidelines early childhood non-formal and informal education. Jakarta. Indonesia.

Risky, S. (2016). Construct of creative thinking assessment on divergent and convergent ability. Internation Journal Of Advance Research And Innovative Ideas In Education, 2(4), 1034-1041.

Suara, M. (2013). Salary of honorary teachers is very less. Indonesia: Central Java.

Torrance, E. P. (1976). The influence on creative thinking of locus of control, cooperation and sex. Paper Presented to the American Psychological Association, Devision 15, Washington. 
Torrance, E. P. (1976). Future careers for gifted and talented students. Gifted Child Quarterly, 20, 142-156.

\section{Turkish Abstract \\ Semarang, Endonezya'da erken Çocukluk Eğitimi Öğretmenlerinin Yaratıcılığı Üzerine Gelir, Deneyim ve Akademik Yeterliliğin Etkisi}

$\mathrm{Bu}$ çalışma, (1) erken çocukluk eğitimi öğretmenlerinin öğretim yaratıcılığ akademik yeterlilik arasındaki karşılıklı ilişki; (2) öğretmenlerin yaratıcılığını Semarang'daki yeteneğini etkileyen baskın faktörleri bulmak için yapılmıştır. Bu araştırma, öğretmenlerin gelirleri (X1), deneyim (X2), akademik yeterlilik (X3) ve öğretmenin yaratıcılığını (Y) içeren dört değişkenli deneysel bir tasarım kullanmaktadır. Sonuçlar, açıklayıcı analitik sonuçlardaki Lise (SMA) ve 2 yıllık diploması olan ortalama eğitim seviyesi aralığının 1.4 olduğunu (D2) gösterdiğini göstermektedir. Bu arada, erken çocukluk eğitimi öğretmenlerinin gelirinin ortalama 191, 991 IDR olduğu ve çok düşük olduğu belirtilmiştir.

Anahtar Kelimeler: etki, gelir, deneyim, eğitim, erken çocukluk eğitimi öğretmenleri

\section{French Abstract}

L'Influence de Revenu, Expérience et Qualification Universitaire sur la Première Créativité de Professeurs d'Enseignement(Éducation) Chilhood dans Semarang, l'Indonésie

Cette étude a pour but de déterminer : (1) l'intercorrélation entre revenu, expérience et qualification universitaire avec la créativité d'enseignement de professeurs d'éducation préscolaire; (2) pour découvrir les facteurs dominants qui affectent la capacité de la Créativité des professeurs dans Semarang. Cette recherche utilise un design(une conception) expérimental avec quatre variables, y compris le revenu des professeurs (X1), l'expérience (X2), la qualification universitaire $(\mathrm{X} 3)$ et la créativité enseignante $(\mathrm{Y})$. Les résultats montrent que : (1) les résultats analytiques descriptifs montrent que la gamme de niveau d'enseignement(éducation) moyenne est 1.4 ou le Lycée (SMA) et diplôme (D2) de 2 années. En attendant, le revenu des professeurs de petite enfance est à la moyenne de 191, 991 IDR ou est toujours catégorisé dans très bas.

Mots Clés: influence, revenu, expérience, éducation, professeurs d'éducation préscolaire 


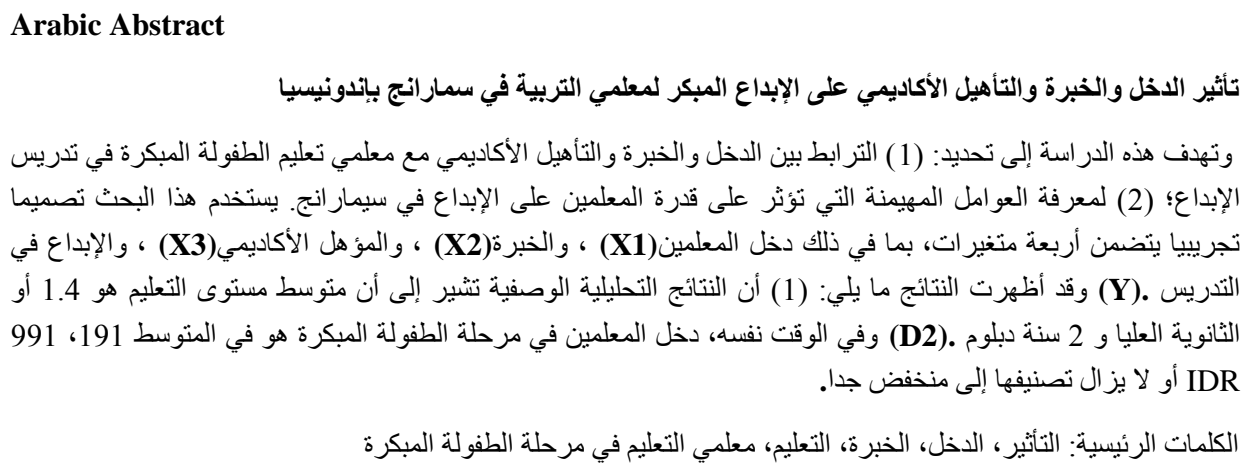

\section{German Abstract}

Der Einfluss von Einkommen, Erfahrung und akademischer Qualifikation auf die Kindergarten Lehrer Kreativität in Semarang, Indonesien

Diese Studie zielt darauf ab, festzustellen: (1) die Interkorrelation zwischen Einkommen, Erfahrung und akademischen Qualifikation mit der frühen Kindheit Bildung Lehrer 'Lehre Kreativität; (2) um herauszufinden, die dominierenden Faktoren, die die Fähigkeit der Lehrer Kreativität in Semarang beeinflussen. Diese Forschung verwendet ein experimentelles Design mit vier Variablen, darunter das Einkommen der Lehrer (X1), die Erfahrung (X2), die akademische Qualifikation (X3) und die Kreativität (Y). Die Ergebnisse zeigen, dass: (1) die deskriptiven analytischen Ergebnisse zeigen, dass die durchschnittliche Bildung Ebene 1,4 oder Senior High School (SMA) und 2 Jahre Diplom (D2). Inzwischen ist das Einkommen der frühen Kindheit Lehrer im Durchschnitt von 191, 991 IDR oder ist noch in sehr niedrig kategorisiert.

Schlüsselwörter: einfluss, einkommen, erfahrung, bildung, frühkindliche bildung lehrer 


\section{Malaysian Abstract \\ Pengaruh Pendapatan, Pengalaman, dan Kelayakan Akademik pada Kreativiti Guru Pendidikan Awal Anak-anak di Semarang, Indonesia}

Kajian ini bertujuan untuk menentukan: (1) intercorrelation antara pendapatan, pengalaman, dan kelayakan akademik dengan kreativiti mengajar guru pendidikan awal kanak-kanak; (2) mengetahui faktor dominan yang mempengaruhi kemampuan kreativiti guru di Semarang. Kajian ini menggunakan reka bentuk eksperimen dengan empat pembolehubah, termasuk pendapatan guru (X1), pengalaman (X2), kelayakan akademik (X3), dan pengajaran kreativiti (Y). Keputusan menunjukkan bahawa: (1) keputusan analitis deskriptif menunjukkan bahawa tahap pendidikan rata-rata adalah 1.4 atau Sekolah Menengah Atas (SMA) dan 2 tahun diploma (D2). Sementara itu, pendapatan guru pendidikan awal kanak-kanak adalah pada purata 191, 991 IDR atau masih dikategorikan menjadi sangat rendah.

Kata Kunci: pengaruh, pendapatan, pengalaman, pendidikan, guru pendidikan awal kanak-kanak

\section{Russian Abstract \\ Влияние Дохода, Опыта и Академической Квалификации на Творчество Учителей Раннего Детства в Семаранге, Индонезия}

Целью этого исследования является определение: (1) интеркорреляций между доходом, опытом и академической квалификацией, наряду с творчеством обучения учителей раннего детства; (2) выяснение доминирующих факторов, которые влияют на способность творчества преподавателей в Семаранге. В этом исследовании используется экспериментальный дизайн с четырьмя переменными, включая доход учителей (X1), опыт (X2), академическую квалификацию (X3), и преподавание творчества (Y). Результаты показывают, что: (1) описательные аналитические результаты показывают, что средний уровень образования составляет 1,4 или Старшая Средняя Школа (SMA) и 2 года диплом (D2). Между тем, доход учителей раннего детства составляет в среднем 191 год, 991IDR и по-прежнему относится к очень низким.

Ключевые Слова: влияние, доход, опыт, образование, учителей раннего детства 